\title{
Educating the Ontological Model of Intellectual Capital Devel-opment Using the Method "Categorial Series"
}

\section{Educar el modelo ontológico del desarrollo del capital in-telectual utilizando el método "Serie categórica"}

\author{
Olga V. Nedoluzhko \\ Vladivostok State University of Economics and Service, Russia \\ ORCID: https://orcid.org/0000-0002-8701-6376 \\ Evgeniya A. Nigay \\ Vladivostok State University of Economics and Service, Russia \\ ORCID: https://orcid.org/0000-0003-0858-5835
}




\section{Summary}

The development of intellectual capital at the macro- and mesoscale is the main tool for the transition of the economy to a progressive sixth technological mode, and at the level of an individual organization it ensures its stable position and high competitiveness in the market. However, training and educating its applications are of a great importance. A prerequisite for an effective implementation of this process is the formation of a systemic idea about the phenomenon of intellectual capital, the composition of its elements, the sequence of stages and the necessary conditions for its formation. To solve this problem, the article proposes to use a categoricalsystem methodology, in particular, the method of "categorical series". Using the method, the analysis and a comprehensive description of intellectual capital development within the categories of the subject area is performed. The main characteristics of cognitive activity at various stages of intellectual capital development are determined. An ontological model of intellectual capital, which is based on the comparison of concept pairs in accordance with the nature of the contradictions developing between them, is proposed. Application of the model makes it possible to determine some promising areas for the development of intellectual capital, taking into account available resources, as well as to formulate the requirements for the composition of resources to obtain a certain type of intellectual capital. A further prospect of the obtained model use is the development of a full-fledged scientific theory of intellectual capital, including, in addition to its constituent element description, the determination of their formation stage sequence and the mechanism of their interaction. The use of this theory will make it possible to implement effective managerial influences on intellectual capital in order to increase the level of its systemic and organizational complexity. The presented results can be applied in legislative activity and in the development of program documents of the Government and the constituent entities of the Federation aimed at the Russian economy change.

Keywords: Intellectual Capital; The Method of Categorical Series; The Central Element; Explicit Knowledge; Implicit Knowledge; Cognitive Activity; The Point of Unstable Equilibrium; Middle Elements; Additional Elements.

\section{Resumen}

El desarrollo del capital intelectual a escala macro y mesoescala es la herramienta principal para la transición de la economía a un sexto modo tecnológico progresivo, y al nivel de una organización individual asegura su posición estable y alta competitividad en el mercado. Sin embargo, la capacitación y educación de sus aplicaciones son de gran importancia. Un requisito previo para una implementación efectiva de este proceso es la formación de una idea sistémica sobre el fenómeno del capital intelectual, la composición de sus elementos, la secuencia de etapas y las condiciones necesarias para su formación. Para resolver este problema, el artículo propone utilizar una metodología de sistema categórico, en particular, el método de "series categóricas". Utilizando el método, se realiza el análisis y una descripción completa del desarrollo del capital intelectual dentro de las categorías del área temática. Se determinan las principales características de la actividad cognitiva en diversas etapas del desarrollo del capital intelectual. Se propone un modelo ontológico de capital intelectual, que se basa en la comparación de pares de conceptos de acuerdo con la naturaleza de las contradicciones que se desarrollan entre ellos. La aplicación del modelo permite determinar algunas áreas prometedoras para el desarrollo del capital intelectual, teniendo en cuenta los recursos disponibles, así como para formular los requisitos para la composición de los recursos para obtener un cierto tipo de capital intelectual. Otra posibilidad del 
uso del modelo obtenido es el desarrollo de una teoría científica completa del capital intelectual, que incluya, además de la descripción de su elemento constituyente, la determinación de su secuencia de etapa de formación y el mecanismo de su interacción. El uso de esta teoría permitirá implementar influencias gerenciales efectivas en el capital intelectual para aumentar el nivel de su complejidad sistémica y organizacional. Los resultados presentados pueden aplicarse en la actividad legislativa y en el desarrollo de documentos de programas del Gobierno y las entidades constitutivas de la Federación dirigidos al cambio de la economía rusa.

Palabras clave: Capital intellectual; Método de series categóricas; Elemento central; Conocimiento explícito; Conocimiento implícito; Actividad cognitive; Punto de equilibrio inestable; Elementos intermedios; Elementos adicionales.

\section{Introduction}

As a progressive vector for the development of the domestic economy, its transformation from an export-oriented model is determined, as this model has shown its failure due to the finiteness of material resources. The transformation takes place to an innovative model based on the use of flexible automated production, space technologies, global information systems, genetic engineering and molecular biology, and active use of renewable energy sources. In the future, these processes will ensure its transition to the sixth technological mode (Lvov, 1990; Kondratiev, 2002; Glazyev, 2005; Krasova et al., 2018; On the Concept of Russian Federation long-term socio-economic development for the period until 2020: the order of the RF Government, 2008). The indicated direction is fixed in state policy by a number of documents (Shashlo \& Petruk, 2017; The forecast of scientific and technological development of Russia for the period until 2030; On the Strategy of the Russian Federation scientific and technological development: The Decree of the RF President on 01.12.2016; On approval of the Russian Federation state program "Development of education": Decree of the RF Government, 2017; The state program "Scientific and technological development of the Russian Federation": The Decree No. 377, 2019) and determines the growing role of intangible production factors, in particular, the intellectual capital of an organization. The organization personnel, the specifics of production and management processes, its business reputation and unique interaction tools with customers begin to play a decisive role in a unique market position development for a company (Edvinsson \& Malone, 1997). Obviously, in order to ensure a competitive position in the market, the organization management must take effective measures to form and develop its intellectual capital, which determines the need for its study and getting answers to the questions about the elements that make up its structure, the nature of their interaction, possible development levels and the conditions of transition from one level to another.

A systematic approach is used as the main approach to the study of intellectual capital. In particular, L. Edwinsson and M. Malone consider the intellectual capital of an organization as the combination of human and structural capital (The state program "Scientific and technological development of the Russian Federation": The Decree No. 377, 2019). J. Ruus, S. Pike, and L. Fernstrom distinguish human resources, relative resources and organizational resources (Shaslo et al., 2018) as the part of intellectual capital elements. On the whole, T. Stuart adheres to a similar point of view, designating human, structural and consumer capital (Roos et al., 2008) as the part of intellectual capital elements. According to E. Brooking, intellectual capital is the combination of human assets, intellectual property, infrastructure and market assets (Stewart, 1998). B.B. Leont'ev believes that the main components of intellectual capital development are intangible assets and knowledge bases owned by an organization, in combination with specific relations with 
other business entities (Brooking, 1996). V.G. Zinov refers knowledge, experience and key competencies of corporation employees, the relationship of the corporation with partner organizations and customers, which together provide the formation of added value and specific competitive advantages of the organization (Leontiev, 2002) to the intellectual capital. M.A. Meshcheryakova defines intellectual capital as some combination of a company brand, its relations with the external environment representatives (partners and customers), as well as the intellectual potential of its employees (Zinov, 2007). The presented works reveal in detail the components of intellectual capital phenomenon. Nevertheless, in order to ensure the consistent implementation of its formation stages, it is necessary to have an idea of these stages and the conditions for the transition from one stage to another. In this situation, the categorical series method is an effective tool, which allows you to select and formulate a problem by constructing a high-quality model of an object, which reflects the dynamics of its development and the main (possible) directions of its study.

\section{Methods}

The use of a systematic approach to intellectual capital phenomenon made it possible to determine its structural components in sufficient detail, however, the absence of a dynamic aspect can be noted as the drawback of the indicated works, i.e. they do not determine the possible conditions and the main directions of its development. This study is aimed at this problem solution, the purpose of which is to study the phenomenon of the organization intellectual capital on the basis of its component determination and the nature of their interaction, taking into account the contradictions between them arising from the limited resources available to the organization. The designated goal achievement will help to identify possible ways of intellectual capital formation and development, taking into account the resources available to the organization and the ways of their use. During the previous stages of the study, the definition of intellectual capital was constructed by using two-level triadic decoding of the basic category in combination with formal logic (Meshcheryakova, 2010). Nevertheless, in order to formulate the definition of the phenomenon under study on the basis of category identification that decipher it, and to identify possible scenarios for the development of a system object, you can use the categorical series method, which makes it possible to analyze the trends of the object change and the main directions of its study (Nedoluzhko, 2016). The structure and elements of the categorical series can be schematically depicted in the form of a pendulum taking into account the type of its behavior. The categorical pendulum method allows you to create categorical model-schemes that reflect the implementation of development processes under the influence of opposite trends. It illustrates the systemic-cybernetic interpretation of dialectical laws and makes it possible to display two classes of processes: deterministic and non-equilibrium. The method shows the development of an object, taking into account the emerging contradictions, the transition of quantitative changes to qualitative ones, a return to the initial state at a new level (negation of negation). Currently, it is effectively used to study system objects in sociology, medicine, psychology, and other fields of scientific knowledge (Razumov, 2008; Aksyutina, 2012; Fomenko \& Krikukha, 2017; Kozlova, 2012; Shtapova, 2009).

The basic categories of the method include the following types:

- Central element (CE) - a category relative to which a categorical series is built. Opposite components are highlighted in it. This is the point of some stable equilibrium (PSE) of the system (to which the weight of the pendulum is attracted);

- Point of stable equilibrium (PSE) - a state of system rest that does not require special efforts to maintain. This is a region of states to which deterministic development scenarios are 
pulled together;

- The point of unstable equilibrium (PUE) is the state of system rest, which requires special (additional) efforts to maintain. This is an area of states from which the process of selforganization in unstable systems begins;

- Middle elements (ME) - indicate the state of system deviation from the PSE (the position of the pendulum load deviation). These are some opposites, fixing two states in CE development;

- additional elements (AE) - extreme deviations for the system state. The first of them precedes the $\mathrm{CE}$ (AE1), the second fixes a new quality, into which the CE passes (AE2);

- uncertainty (U) - a characteristic of the system openness to external influences (disturbances), not provided for by the system dynamics, but possible within the larger system;

- categorical series trends (CST) - the forces that initiate the system deviation (pendulum load) from the PSE. They are determined by the contradictions between CE (AE) and unfold between them;

- the trends of uncertainty (TU) - specific mechanisms within which the effect of uncertainty (U) on CE and SE occurs. They express external influences on these elements and act, in fact, as interference, requiring compensation by them;

- the bonds of elements in the CS or series bonds (SB) organize the CS in a single openloop circuit (AE1 - AE2).

\section{Results}

The basic conditions of "categorical series" method applicability are the possibility of distinguishing the change of three or more qualitative states during the development of the object under study, the presence of resource movement in opposite directions in it and the sensitivity of the object to external influences. The intellectual capital of the organization meets all of the indicated conditions. The representation of intellectual capital phenomenon in the categories of the method is shown on Fig. 1. 


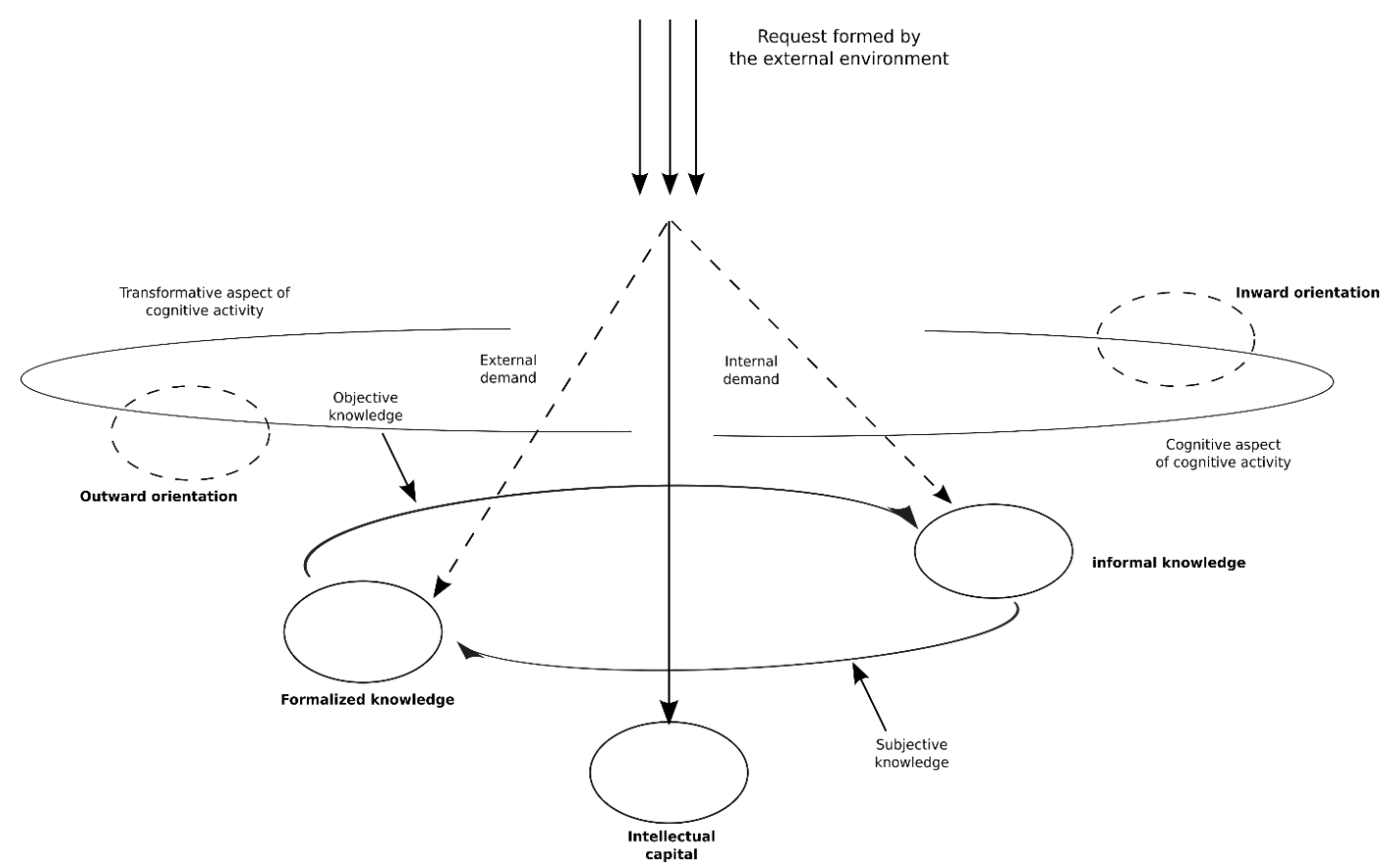

Figure 1. Categorical series of the central element "intellectual capital" *

* Source: compiled by the authors.

The basic categories of the method are implemented in relation to the studied object as follows:

- The central element (CE) - in this case, it is a certain level of intellectual capital development;

- the point of sustainable equilibrium (PSE) - represents the level of intellectual capital development formed at this stage, based on the resources available in the organization (types of intellect) and taking into account the nature of the impact on them (the type of implemented cognitive activity);

- Unstable equilibrium point (UEP) - the required level of intellectual capital development, taking into account the request formed by the external environment;

- Middle elements (SE) - these are two types of knowledge in the organization, taking into account their nature: explicit and implicit. Explicit knowledge is directed outward and is objective, implicit knowledge is largely determined by the subjective characteristics of a carrier and is oriented inward;

- Additional elements (AE) - they represent two main aspects of cognitive activity. The first of these is the cognitive aspect, which involves the accumulation of necessary knowledge, ensuring the formation of the corresponding types of knowledge, their accumulation, i.e. it is oriented inward. The second aspect is transformative, which represents an active position in relation to the external environment and provides changes in it by using the appropriate type of knowledge. It is directed outward; 
- uncertainty $(\mathrm{H})$ - in relation to the intellectual capital of an organization, it represents a request formed by the external environment in relation to the organization and involving the formation of a certain type of intellectual capital, the presence of which will allow the organization to be competitive in the market;

- The trends of the categorical series (TCS) - in this case, they are determined by the contradiction between the orientation of the organization cognitive activity outward and inward. The choice of the corresponding type of cognitive activity occurs under the influence of a request formed by the external environment, however, the necessary condition for the effective implementation of a certain type of activity is the availability of the necessary resources and employee skills to implement the corresponding type of activity;

- Trends of uncertainty (TU) - they are expressed in the impact of demand formed by the external environment, i.e. TNR are formed during the interaction of TU with internal resources of the organization;

- Element bonds in the KR or series bonds (SB) - at the initial stages of intellectual capital development, the activities focused on a specific employee (training, involvement) are implemented, the production phase is also carried out by a specific employee, but within the company. Self-improvement is carried out by an individual employee, but through a more complex type of activity, and only at the stages of customer-oriented rationalization and innovation, the use of organizational knowledge occurs outside the organization, in the context of its interaction with the external environment, and primarily with customers.

\section{Discussion}

The following types of contradictions arise between the possible provisions of the CE, due to the presence of opposite pairs of categories:

1) explicit knowledge - implicit knowledge;

2) cognitive activity directed outward - cognitive activity directed inward;

3) cognitive aspect - transformative aspect.

The formation of the first pair is conditioned by different nature of knowledge, which is the result of intellectual capital development. In the first case, knowledge is formalized and can be translated by the means of a formal, systematic language. In the second case, it is personal and therefore difficult to formalize and disseminate (Teslinov, 2009).

The existence of the second pair is determined by the different nature of the need for one or another form of intellectual capital, which can be put forward from the outside in relation to the subject that carries out cognitive activity (leadership requirements), or can come from the subject itself (employee's internal awareness of the need for change).

The emergence of the third pair is due to differences in the nature of cognitive activity implementation, which can be cognitive during the initial stages of intellectual capital development (training, involvement), and change it during subsequent stages (production rationalization, self-improvement, customer-oriented rationalization, innovative activity). The resulting pairs make it possible to use a three-dimensional categorical series, i.e. CE moves from lower to higher levels of development in a three-dimensional coordinate system. The position of the $\mathrm{CE}$ at each stage of its development can be determined using the table 1. 
Table 1.

Characteristics of CE position during each stage of its development *

\begin{tabular}{cccc}
\hline Development stage & Knowledge type & $\begin{array}{c}\text { Type of } \\
\text { direction }\end{array}$ & Activity type \\
\hline Intellectual learning capital & Implicit & Inside & Cognitive \\
\hline $\begin{array}{c}\text { IC } \text { of involvement } \\
\text { IC of manufacturing } \\
\text { rationalization }\end{array}$ & Implicit & Inside & Cognitive \\
\hline IC of self improvement & Implicit & Inside & Transformative \\
\hline Customer oriented IC & Explicit & Inside & Transformative \\
\hline Innovative IC & Explicit & Outside & Transformative \\
\hline
\end{tabular}

* Source: compiled by the authors.

In accordance with the table data, during the initial stage of intellectual capital development, cognitive activity is carried out, which is oriented inside the subject. During the training stage of the intellectual capital development, an employee acquires the necessary knowledge and skills in the process of work under the guidance of more experienced colleagues. In this case, he carries out the activity aimed at the object without its transformation (cognition) and provides him with the formation of knowledge about this object (internal orientation). These features determine the specific nature of knowledge, which is rather difficult to formalize, since it is implicitly transmitted in the process of group work.

During the involvement stage of intellectual capital development, value-oriented activity is implemented (Polanyi, 1966; Nedoluzhko et al., 2016), which is the perception of reality through its assessment, that is, in the process of daily work performance, an employee begins to form a sense of ownership during the events taking place in the organization and the influence of their results on the effectiveness of the company. This activity prepares the corresponding emotional background for his further work, i.e. it is also directed inside the subject, and can also be described as cognitive from the point of view that an employee does not change the object during its implementation, but forms an emotional attachment to it, being involved in intraorganizational processes. The nature of knowledge in this situation is also implicit, since it is even more difficult to formalize the ongoing process of an employee involvement in the company affairs.

During the transition to more progressive stages, the active position of the subject in relation to the object is strengthened, as well as the use of non-standard operations and procedures, which indicates the activation of creativity in the work being done. In particular, during the production stage of intellectual capital development, transformative cognitive activity is carried out, i.e. the impact of the subject on the object, ensuring the implementation of certain changes. An employee has sufficient knowledge and is emotionally prepared in order to gain independence for the most rational method selection to solve the problem in accordance with the implemented strategy of activities. The result of this process is obtaining more advanced, streamlined production technologies, i.e. there is an active nature of activity, the transformation of the object. At the same time, the activity itself retains its internal orientation, i.e. does not go beyond the organization, however, formalizing the ongoing changes is already quite simple, because they are expressed in a clearly fixed transformation of production processes. 
During the next stage, an employee implements a new type of cognitive activity, due to his internal desire for self-improvement, which entails going beyond the alternatives traditionally offered in this particular situation. This activity is also active, but directed inside the employee himself, ensuring the transformation of mental processes occurring in him. Formalization of these changes is also quite difficult, since they occur more likely on the mental level, and the employee often does not realize the ongoing transformation.

The next two stages of intellectual capital development are characterized by the external orientation of the worker cognitive activity. In the first case, when the formation of customeroriented intellectual capital occurs, the object of the employee's efforts is the organization relations with the external environment, primarily with its customers. Thus, more effective mechanisms are formed for the interaction of the company with counterparties. The activity of the employee is active, providing the transformation of the object. The knowledge created in the process of its implementation is explicit, since the transformation of the possible ways of the organization interacting with customers is subject to a clear fix.

During the process of innovative intellectual capital development, the cognitive activity of employees is also directed outside the organization. It provides a vision of an economic result possibility creation in the surrounding world and is aimed at its capitalization. The activities of employees, as during the stage of intellectual capital development for self-improvement, presupposes going beyond the boundaries of traditional alternative methods of action, the object in this case is not even the processes of interaction between the organization and the customers, but the very concept of this interaction, which determines the active nature of the transformation processes and explicit the nature of knowledge, since it is necessary to formalize it in the form of a trade secret regime introduction or another way of intellectual activity result record in order to prevent competitors from receiving information on innovation.

\section{Conclusion}

Thus, the use of categorical series method in relation to the intellectual capital of the organization allowed to obtain the following results.

1. Comprehension and all-inclusive description of intellectual capital development in the categories of the subject area is made.

2. The main features of cognitive activity as a fundamental characteristic of intellectual capital phenomenon at various stages of its formation have been determined.

3. A qualitative model of intellectual capital is built, based on the comparison of concept pairs in accordance with the nature of the contradictions that arise between them. Its use allows you to determine the possible trends of intellectual capital development, taking into account the available resources.

Using the method will allow to determine programs and possible trajectories of scientific research for intellectual capital phenomenon, as well as to formalize the categorical pendulum model developed for the subject area in the language of dynamic information system theory. Based on the obtained results, it is possible to formulate a full-fledged scientific theory of intellectual capital in the future, which, in addition to the description of its constituent elements, includes the sequence of their formation stages and the mechanism for their interaction. Using this theory will provide an opportunity to carry out effective managerial influences on intellectual capital in the direction of its systemic and organizational complexity increase. 


\section{References}

Aksyutina, Z. A. (2012). The relationship of interaction and social education in the categoricalsystem representation. Bulletin of the Omsk University, 4, 163-169.

Brooking, A. (1996). Intellectual Capital: Core Asset for the Third Millennium Enterprise. London: Thompson International Business Press, $224 \mathrm{p}$.

Edvinsson, L., \& Malone, M. (1997). Intellectual Capital: Realizing Your Company's True Value by Finding Its Hidden Brain-power. HarperCollins, New York, NY, 240 p.

Fomenko, A. A., \& Krikukha, Yu. Yu. (2017). Ontological model of technical and tactical training management for qualified Greco-Roman style wrestlers. Scientific almanac, 2-2(28), 220223.

Glazyev, S. Yu. (2005). Choice of the future. M.: Algorithm, 352 p.

Kondratiev, N. D. (2002). Large cycles of market conditions and foresight theory: selected works. M.: Economics, 768 p.

Kozlova, K. S. (2012). Service industry (socio-philosophical analysis). Omsk, 128 p.

Krasova, E. V., Klindukh, R., \& Krasko, A. (2018). Cyclicality of innovative development in entrepreneurship. Amazonia Investiga, 7(17), 21-30.

Leontiev, B. B. (2002). The price of intelligence. Intellectual capital in Russian business. M.: Shareholder, $196 \mathrm{p}$.

Lvov, D. S. (1990). The effectiveness of technical development management. M.: Economics, 256 p.

Meshcheryakova, M. A. (2010). The problem of intellectual capital measuring in the modern economy. Bulletin of Moscow University. Series 6. "Economics", 1, 3-14.

Nedoluzhko, O. V. (2016). A new approach to the formation of the conceptual space for intellectual capital phenomenon of an organization. Bulletin of the Udmurt University. Series "Economics and Law", 26(2), 42-49.

Nedoluzhko, O. V., Varkulevich, T. V., \& Baturina, O. A. (2016). Evolution of Individual's Intellect as Basis for Forming Intellectual Capital of Organization. Journal of Advanced Research in Law and Economics, 2(16), 313 - 321.

On approval of the Russian Federation state program "Development of education": Decree of the RF Government (December 26, 2017) No. 1642 [Electronic resource]. RF Government: official site. Access mode: http://static.government.ru/media/files/313b7NaNS3VbcW7qWYslEDbPCuKi6lC6.pdf.

On the Concept of Russian Federation long-term socio-economic development for the period until 2020: the order of the RF Government (November 17, 2008) N 1662-r (amended on September 28, 2018) [Electronic resource]. ConsultantPlus: official site. Access mode: http://www.consultant.ru/document/cons_doc_LAW_82134/28c7f9e359e8af09d7244d8 033c66928fa27e527/.

On the Strategy of the Russian Federation scientific and technological development: The Decree of the RF President on 01.12.2016 [Electronic resource]. President of Russia: official site. Access mode: http://kremlin.ru/acts/bank/41449/page/1.

Polanyi, M. (1966). The Tacit Dimension. London: Routledge \& Kegan Paul, 128 p.

Razumov, V. I. (2008). Categorical-systemic methodology in the preparation of scientists: textbook. Entry. Art. by A.G. Teslinova. Omsk: Omsk state Univ, 267 p.

Roos, G., Pike, S., \& Fernström, L. (2008). Intellektual'nyi kapital: praktika upravleniya [Managing Intellectual Capital in Practice]. St. Petersburg, SPbSU Publ, 448 p.

Shashlo, N. V., \& Petruk, G. V. (2017). Innovative-oriented cluster systems as performance growing points in agroindustrial complex of the Far East of Russia. Journal of Engineering and Applied Sciences, 12(S1), 5806-5813.

Shaslo, N., Petruk, G., \& Korostelev, A. (2018). Determinants of integration interaction among the subjects of the entrepreneurial innovation ecosystem of macro region. Amazonia Investiga, 7(13), 351-363 
Shtapova, I. S. (2009). The concept of the industry market and its cognitive representation. Economics and Management, 5(54), 185-190.

Stewart, T. (1998). Intellectual capital: the new wealth of organization. New York: Crown Business Group, 320 p.

Teslinov, A. G. (2009). Conceptual design of complex solutions. St. Petersburg: Peter, 288 p.

The forecast of scientific and technological development of Russia for the period until 2030 [Electronic resource]. Government of the Russian Federation: official site. Access Mode: http://static.kremlin.ru/media/acts/files/ 0001201612010007.pdf.

The state program "Scientific and technological development of the Russian Federation": The Decree No. 377 (March 29, 2019) [Electronic resource]. President of Russia: official site. Access mode: http://static.kremlin.ru/media/acts/files/0001201612010007.pdf.

Zinov, V. G. (2007). Intellectual property of a modern enterprise: legal and economic aspects in the light of WTO joining prospects for Russia. Materials of NPK "Intellectual Property as a Tool of a Market Economy". Part 1. Tver: TIITP. 